\title{
Intoxicação por Sida carpinifolia (MAlvaCEAE) em caprinos*
}

\author{
EDSON MOLETA COLODEL
}

\author{
David Driemeier (Orientador - UFRGS)
}

Banca: Aldo Gava (UDESC), Claudio Barros (UFSM), Maria Isabel Edelweiss (UFRGS)

Descrevem-se os achados clínicos e patológicos da intoxicação espontânea e experimental por Sida carpinifolia em caprinos. Os achados da intoxicação espontânea serão apresentados em dois artigos. Um deles relata pela primeira vez uma doença investigada em de 1997 no município de Lajeado, RS. O outro artigo descreve os aspectos clínicos e patológicos da intoxicação espontânea em dois surtos adicionais, ocorridos no ano de 2001 no município de Glorinha e em Porto Alegre, RS. Nesses trabalhos caracterizou-se através de exames clínicos, patológicos e ultra-estruturais uma doença de depósito lisossomal. Por análise do padrão de coloração com histoquímica de lectinas, em cortes histológicos do cerebelo, pâncreas e fígado, observou-se afinidade de marcação especificamente com Concanavalia ensiformis, Triticum vulgaris e T. vulgaris-succinilado, similar ao de alfa-manosidose hereditária ou adquirida por ingestão de plantas do gênero Swainsona, Oxytropis, Astragalus e Ipomoea. A caracterização do princípio tóxico da planta, associada com as lesões que induzem o quadro clínico, foi apresentada em forma de um artigo. Para caracterizar o quadro clínico e patológico, foi administrada a 14 caprinos, divididos 7 grupos de dois indivíduos cada, Sida carpinifolia, secada a sombra e triturada por períodos de 15, 20, 40, 60, 90 e 120 dias. O consumo diário variou de 14 a $21 \mathrm{~g} / \mathrm{kg}$ nos diferentes grupos durante o experimento. Para outros 3 caprinos efetuou-se a administração forçada da planta seca por via oral, de 10 a 12,5 $\mathrm{g} / \mathrm{kg}$, durante 30 dias. $\mathrm{O}$ quadro clínico até os 30 dias de consumo da planta consistia principalmente de letargia, alteração intermitente da consistência das fezes e diminuição no ganho de peso. Por volta de 40 dias de consumo, os caprinos demonstravam também incoordenação motora aos estímulos e após os 60 dias de consumo ocorria incoordenação motora espontânea, com tremores musculares de cabeça e pescoço principalmente. As principais alterações histológicas e ultra-estruturais foram vacuolização e tumefação citoplasmática em neurônios, células da tireóide e pâncreas observadas com intensidade leve após 15 dias de consumo e acentuada após os 90 dias de consumo de Sida carpinifolia.

Descritores: Sida carpinifolia, swainsonina, doença de depósito lisossomal, caprino, planta tóxica. 


\title{
Experimental poisoning by Sida carpinifolia (MALVACEAE) in goats**
}

\author{
EDSON MOLETA COLODEL
}

\author{
David Driemeier (Adviser)
}

Committee: Aldo Gava (UDESC), Claudio Barros (UFSM), Maria Isabel Edelweiss (UFRGS)

The clinical and pathological findings in the spontaneous and experimental Sida carpinifolia poisoning in goats are descrobed. Two papers that report Sida carpinifolia toxicosis in goats are the basis of this work. The initial outbreak of Sida carpinifolia toxicosis, was investigated in 1997 and occurred in the county of Lajeado, Rio Grande do Sul (RS), Brazil. Another article includes our observations on two additional outbreaks of Sida carpinifolia poisoning, which occurred in the counties of Glorinha and Porto Alegre in 2001. A lysosomal storage disease was characterized through clinical, pathological, and ultrastructural exams. The lectin histochemistry applied to sections of cerebellum, pancreas and liver revealed strong reactions with Concanavalia ensiformis, Triticum vulgaris and succinil-T. vulgaris. This binding pattern characterizes an alpha-manosidosis similar to that observed in other plant poisonings including the genera Swainsona, Oxytropis, Astragalus, and Ipomoea. The characterization of the swainsonine alkaloid associated with the lesions that induced the clinical picture is presented in a third article. The clinical and pathological picture was reproduced by dosing goats with dry and crushed Sida carpinifolia leaves. Fourteen goats were distributed in seven groups of two animals, which consumed the plant during 15, 20, 40, 60, 90 and 105 days. The daily consumption varied from 14 to $21 \mathrm{~g} / \mathrm{kg}$ in different groups. Additional three goats were forced fed the plant at 10 to $12.5 \mathrm{~g} / \mathrm{kg}$, for 30 days. Up to the $30^{\text {th }}$ day of consumption signs included mainly lethargy, intermittent alteration in the consistence of feces and lower average daily weight gains. At the $40^{\text {th }}$ day, goats demonstrated incoordination to the exercise, and after the $60^{\text {th }}$ day of consumption spontaneous incoordination gait and muscular tremors of the head and neck were also noticed. The main histological and ultrastructural change consisted cytoplasmic vacuolation in neurons, cells of the thyroid and pancreas. These changes were mild' at 15 days of consumption and enhanced after the $90^{\text {th }}$ day of Sida carpinifolia ingestion.

Key words: Sida carpinifolia, swainsonine, lysosomal storage diseases, goats, poisonous plants. 